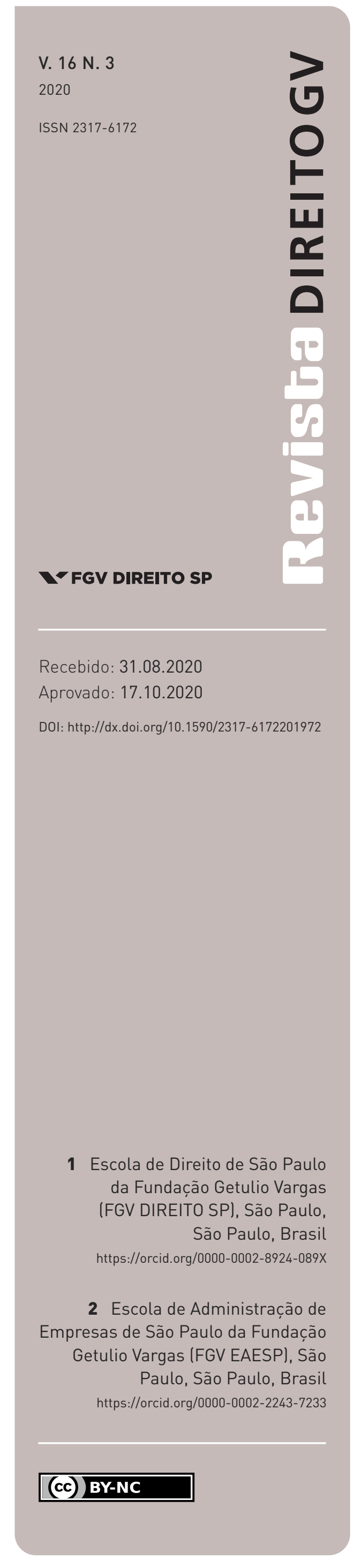

\section{Dogmática jurídica encarnada: a disputa interpretativa em torno das medidas protetivas de urgência e suas consequências para a vida das mulheres}

EMBEDDED LEGAL INTERPRETATION: INTERPRETATIVE DISPUTES REGARDING URGENT PROTECTIVE MEASURES AND ITS CONSEQUENCES TO WOMEN'S LIVES

\author{
Marta R. de Assis Machado e Olívia Landi C. Guaranha
}

\section{Resumo}

0 texto retrata as disputas interpretativas em torno da "natureza jurídica" das medidas protetivas de urgência da Lei Maria da Penha, que se dão na doutrina e nos tribunais. Ao privilegiar o ponto de vista das mulheres na interpretação do direito, chama a atenção para o fato de que uma disputa interpretativa aparentemente anódina de taxonomia conceitual esconde consequências cruciais para a vida e segurança das mulheres. Por meio de entrevistas com atrizes do sistema de justiça e da rede de atendimento às mulheres vítimas de violência, mostra como as interpretações que veem as medidas protetivas como acessórias ao processo impõem ônus injustificado às mulheres para que tenham acesso a um direito conquistado. Além de deixá-las desprotegidas, submetem-nas a procedimentos revitimizadores, limitam as suas alternativas de apoio e suprimem seu espaço de escolha.

\section{Palavras-chave}

Lei Maria da Penha; medidas protetivas de urgência; teoria feminista do direito; interpretação jurídica.

\begin{abstract}
This article portraits the interpretative (doctrinal and judicial) disputes concerning the "legal nature" of urgent protective measures, which are prescribed by the Maria da Penha Statute. By giving privilege to the women's point of view regarding the interpretation of law, this work draws attention to the fact that an interpretative dispute about conceptual taxonomy, although seemingly anodyne, hides crucial consequences to women's lives and safety. We utilized interviews with actresses from the justice system and from assistance network to victims of violence to demonstrate how the interpretation which considers the urgent protective measures accessories to the judicial procedure imposes on women an unjustified burden to a conquered legal right. Besides leaving them unprotected, such interpretation submits women to revictimizing procedures, limits the alternatives of support to the victims and suppresses their choices.
\end{abstract}

\section{Keywords}

Maria da Penha Statute; urgent protective measures; feminist legal theory; legal interpretation. 
When the law must choose among realities, the principle of equality requires that we look to see whose dignity is most at stake, whose point of view has historically been silenced and is in danger of being silenced again, and that, in the ordinary case, we choose that point of view as our interpretation.

Ann Scales, $1992^{1}$

\section{INTRODUÇÃO}

O texto da epígrafe é de Ann Scales, uma autora norte-americana que escreve sobre teoria feminista do direito, em um trecho que fala da necessidade de pensarmos um outro método de interpretação jurídica. Um método que descortine a suposta neutralidade do direito que apenas perpetua as assimetrias estruturais - e que assuma que em toda interpretação jurídica há sempre um ponto de vista privilegiado. Como seria então se olhássemos o direito e a interpretação jurídica a partir “da base”, ${ }^{2}$ ou, em suas palavras, a partir do grupo que tem sua dignidade mais ameaçada, daquelas que sempre foram silenciadas e estão prestes a ser novamente?

É desse ponto de vista que nos propusemos a olhar para o problema jurídico que enfrentamos neste artigo: as disputas interpretativas em torno da "natureza jurídica" das medidas protetivas de urgência da Lei Maria da Penha (LMP). A Lei n. 11.340/2006, que cria no país uma política pública para lidar com a violência doméstica, traz como uma de suas maiores inovações as medidas protetivas de urgência, instrumento jurídico que garante à mulher uma tutela judicial em face do risco de sofrer agressão.

Uma disputa interpretativa aparentemente anódina sobre a natureza jurídica dessas medidas esconde consequências cruciais para as mulheres. As interpretações que as veem como medidas acessórias ao processo impõem ônus injustificado às mulheres, para que tenham acesso a um direito conquistado, além de deixá-las desprotegidas, à mercê de continuarem sofrendo violências que podem ser fatais. Esse não é um risco residual em um país em que as taxas de feminicídio são crescentes. ${ }^{3}$

Exploramos neste artigo como essa disputa se dá na doutrina, em varas de primeira instância e em tribunais e discutimos algumas de suas consequências para a proteção da mulher.

1 Scales (1992).

2 Nesse mesmo texto, Ann Scales discute com Mari Matsuda a ideia de olhar o direito a partir da base, "looking to the bottom" (MATSUDA, 1987).

3 Segundo o Atlas da violência 2019 (IPEA; FBSP, 2019), entre 2007 e 2017 a taxa de homicídio por 100 mil mulheres cresceu 20,7\% no país, passando de 3,9 para 4,7 mulheres assassinadas por grupo de 100 mil mulheres. 
Concretamente, a disputa surge quando se requer o registro da ocorrência criminal ou da representação da vítima para a concessão das medidas protetivas de urgência; ou quando se decide sobre sua duração - se a medida pode persistir, embora o processo penal tenha acabado por razões processuais ou sentença. Ou, ainda, se, para a concessão da medida, é preciso avaliar a consistência das provas ligadas ao crime e sua autoria.

A exigência feita por boa parte dos juízes de que exista um processo penal atrelado à medida protetiva é um obstáculo à proteção da mulher, tanto àquela que opta por não mover processo criminal contra o agressor como àquela que vê o fim do processo penal, mas não o fim da ameaça. Embora questionada por ativistas e defensoras, a adoção desse entendimento na aplicação da LMP reduz o alcance da proteção que a lei dá às mulheres, pune as mulheres pelo exercício de sua autonomia, além de consolidar a via penal como a principal porta de entrada para acessar a política pública de proteção contra violência doméstica. O debate chega às instâncias superiores, mas não se resolve e segue impondo às mulheres o ônus de recorrer ou ver seu direito à proteção cerceado.

Para observar a questão interpretativa em aberto, pesquisamos doutrina e jurisprudência - do Tribunal de Justiça de São Paulo (TJSP) e do Superior Tribunal de Justiça (STJ) -, retratadas nas seções 2 e 3 . Entrevistamos diversas profissionais, ${ }^{4}$ que relataram seus esforços para valer o entendimento da autonomia das medidas e que nos dão um retrato de como se dá a disputa na primeira instância paulista. Além disso, por estarem na ponta do sistema, trazem relatos sobre os efeitos concretos desse debate dogmático na vida das mulheres, o que nos permitiu pensar a interpretação dogmática a partir do ponto de vista das mulheres (seção 4).

Ao final, apresentamos uma possível explicação para o problema da vinculação das medidas protetivas ao processamento criminal, ligada à colonização da lógica penal na interpretação da lei e que chamamos de path dependence criminal. Nossa hipótese é a de que a leitura da lei inovadora e híbrida pela lente penal é consequência do arranjo institucional a que está submetida: diante do pequeno número de Juizados de Violência Doméstica (JVDs)

4 Para esta pesquisa, foram entrevistadas dez profissionais atuantes em diferentes organizações: (i) uma advogada atuante no Comitê Latino-Americano e do Caribe para a Defesa dos Direitos da Mulher (Cladem); (ii) uma advogada atuante em Centro de Defesa e Convivência da Mulher (CDCM) na zona leste de São Paulo; (iii) uma promotora de justiça, atuante no Grupo de Atuação Especial de Enfrentamento à Violência Doméstica do Ministério Público (Gevid); (iv) duas defensoras públicas do Núcleo de Promoção e Defesa dos Direitos da Mulher da Defensoria Pública do Estado de São Paulo (Nudem); (v) uma defensora pública que atua próxima ao JVC de São Miguel Paulista e Itaquera (zona leste de São Paulo); (vi) uma defensora pública atuante nas varas Cível e de Família em Itaquera (também zona leste); (vii) uma gerente de CDCM na zona leste de São Paulo; (viii) uma juíza de JVD atuante na zona oeste de São Paulo; (ix) uma juíza de vara criminal atuante na região metropolitana de São Paulo. As entrevistas foram realizadas entre 2016 e 2018. 
implementados, a lei segue sendo aplicada por juízes que atuam em varas criminais, 14 anos após a promulgação da LMP.

\section{A Lei Maria da Penha e as medidas protetivas de urgência (MPUs)}

Depois de uma batalha de décadas, uma das mais antigas demandas do movimento de mulheres se concretizou no Brasil, com a aprovação da Lei n. 11.340/2006. Apelidada de Lei Maria da Penha, em referência ao caso de violência que resultou na condenação do Brasil no sistema Interamericano de Direitos Humanos, a lei é resultado de uma eficiente campanha do movimento de mulheres, que incluiu a formação de um consórcio de organizações não governamentais (ONGs) feministas, ${ }^{\mathbf{5}}$ a aliança com a Secretaria Especial de Políticas para Mulheres, mobilização internacional e um sério trabalho de advocacy no Parlamento (MACIEL, 2011, p. 102; ALVAREZ, 1998). A lei é considerada uma importante conquista das mulheres, pela história de sua criação, sua popularidade ${ }^{6}$ e importância dos instrumentos que traz para lidar com a questão da violência de gênero. ${ }^{\mathbf{7}}$

Ela representa também uma inovação no ordenamento jurídico brasileiro, por conjugar ações de proteção, punição e prevenção, caracterizando uma política pública de caráter integral de enfrentamento à violência contra a mulher (PASINATO, 2015b, p. 534). Multifacetada, a lei introduz mudanças de várias ordens - no conceito de violência e de família, no tratamento penal dos casos, na estrutura do aparato institucional (a criação dos juizados especiais de violência doméstica, a rede de atendimento às mulheres), no tratamento dado às vítimas e nos instrumentos disponíveis para sua proteção. ${ }^{8}$

5 Referimo-nos aqui, especialmente, ao consórcio de ONGs feministas que atuou fortemente na campanha pela aprovação da lei: Cepia, CFEMEA, Ações em Gênero, Cidadania e Desenvolvimento (Agende), Advocaci, Cladem/Ipê e Thêmis (BARSTED, 2011, p. 28).

6 Segundo a pesquisa Violência doméstica e familiar contra a mulher, publicada pelo Instituto de Pesquisa DataSenado em junho de 2017, 100\% dos entrevistados já tinham ouvido falar da LMP. Desses, 18\% afirmaram conhecer muito sobre a Lei e 77\% afirmaram conhecer pouco. Cf. Senado Federal (2017).

7 Na pesquisa Avaliando a efetividade da Lei Maria da Penha, realizada pelo Instituto de Pesquisa Econômica Aplicada (IPEA) em 2015, os pesquisadores afirmam: "Consideramos que a LMP afetou o comportamento de agressores e vítimas por três canais: i) aumento do custo da pena para o agressor; ii) aumento do empoderamento e das condições de segurança para que a vítima pudesse denunciar; e iii) aperfeiçoamento dos mecanismos jurisdicionais, possibilitando ao sistema de justiça criminal que atendesse de forma mais efetiva os casos envolvendo violência doméstica. A conjunção dos dois últimos elementos seguiu no sentido de aumentar a probabilidade de condenação. Os três elementos somados fizeram aumentar o custo esperado da punição, com potenciais efeitos para dissuadir a violência doméstica” (CERQUEIRA et al., 2015, p. 32).

8 “A Lei Maria da Penha contém um amplo catálogo de medidas de caráter extrapenal destinadas a prevenir a violência doméstica e de gênero de maneira integral. Medidas de longo prazo para o planejamento de políticas 
No campo penal, a lei transformou a violência doméstica em uma circunstância agravante (art. 61, II, $f$, do Código Penal [CP]). e criou uma causa de aumento de pena para as lesões corporais praticadas em ambiente doméstico, alterando a pena de seis meses a um ano de detenção para três meses a três anos de detenção (art. 129, § 9º, do CP). A violência doméstica foi definida para fins legais como qualquer ação ou omissão baseada no gênero que cause morte, lesão, sofrimento físico, sexual ou psicológico e dano moral ou patrimonial à mulher e que ocorra dentro do espaço de convívio dela, de sua família ou em um relacionamento afetivo (art. $5^{\circ}$ da Lei n. 11.340/2006).

Essas mudanças geraram consequências para o cálculo das penas e também determinaram a substituição do processamento das demandas de violência doméstica dos Juizados Especiais Criminais (JECrims) ${ }^{9}$ para os JVDs, com competência cível e criminal. Os JVDs têm o objetivo de acumular as demandas das mulheres vítimas de violência em um só espaço, com pessoal especializado e estrutura, partindo do princípio de que a proteção à mulher será integral se o juiz puder construir uma compreensão mais ampla sobre o complexo contexto das relações domésticas e familiares (CEPIA, 2013, p. 27).

A introdução de MPUs pela Lei é considerada um de seus aspectos mais inovadores (CEPIA, 2013, p. 27). Tais medidas têm por função a proteção de mulheres em risco iminente de violência (LAVIGNE e PERLINGEIRO, 2011; PASINATO, 2015a). Elas também ganham centralidade como resposta às mulheres diante da morosidade do judiciário e da limitação das respostas via direito penal para alterar o cenário de violência (OBSER$\mathrm{VE}, 2010)$.

Dispostas nos arts. 22 a 24 da lei, as medidas são divididas entre aquelas que obrigam o agressor e aquelas que protegem a ofendida. As primeiras visam à restrição da liberdade do acusado e seu contato com a mulher, ${ }^{10}$ ao passo que as segundas visam a proteger a integridade

destinadas à violência contra a mulher e a mudança do olhar da sociedade sobre o fenômeno [...]; medidas de curto prazo ou de realização imediata destinadas a facilitar o acesso a recursos governamentais e a mobilidade da mulher em situação de violência doméstica [...] e, por fim, medidas de contenção e proteção de riscos destinadas a reduzir os riscos decorrentes da situação de violência [...]" (CAMPOS, 2008, p. 253-254, grifos da autora).

9 Os JECrims foram instituídos pela Lei n. 9.099/1995 para julgar as ações criminais contra crimes de menor potencial ofensivo, que são as contravenções penais e os crimes aos quais a lei determina pena máxima não superior a dois anos.

10 A título de exemplo:

“Art. 22. [...] III - proibição de determinadas condutas, entre as quais:

a) aproximação da ofendida, de seus familiares e das testemunhas, fixando o limite mínimo de distância entre estes e o agressor; 
física, ${ }^{11}$ psicológica $^{12}$ e patrimonial ${ }^{13}$ da mulher e seus dependentes. As medidas devem ser aplicadas de imediato pelo juiz caso seja "constatada a prática de violência doméstica e familiar contra a mulher" ${ }^{14}$ não havendo, no texto legal, quaisquer outros requisitos para sua concessão. ${ }^{15}$ Apesar do caminho mais comum percorrido pelas vítimas de violência doméstica começar na delegacia de polícia com a lavratura do Boletim de Ocorrência (B.O.), a lei permite que as medidas sejam pleiteadas pela Defensoria Pública, advogados particulares, pelo Ministério Público ou pela própria mulher (art. 19).

\section{O DEBATE DOGMÁTICO SOBRE A NATUREZA JURÍDICA DAS MEDIDAS PROTETIVAS DE URGÊNCIA}

$\mathrm{Na}$ linguagem da lei, diante da prática de violência doméstica e familiar contra a mulher, as MPUs devem ser concedidas, mantidas ou combinadas com outras quando "direitos reconhecidos nesta Lei forem ameaçados ou violados", se o juiz "entender necessário à proteção da ofendida, de seus familiares e de seu patrimônio" ou "sempre que a segurança da ofendida ou as circunstâncias o exigirem”. O norte para a concessão ou suspensão das medidas é, segundo a lei, a necessidade de proteção da mulher. Não existe previsão legal de vinculação das medidas ao B.O., à representação da vítima, ${ }^{16}$ a um procedimento penal ou cível e tampouco há um limite estabelecido para a sua duração.

b) contato com a ofendida, seus familiares e testemunhas por qualquer meio de comunicação;

c) frequentação de determinados lugares a fim de preservar a integridade física e psicológica da ofendida.”

“Art. 23. [...] II - determinar a recondução da ofendida e a de seus dependentes ao respectivo domicílio, após afastamento do agressor;

III - determinar o afastamento da ofendida do lar, sem prejuízo dos direitos relativos a bens, guarda dos filhos e alimentos.”

12 "Art. 23. [...] I - encaminhar a ofendida e seus dependentes a programa oficial ou comunitário de proteção ou de atendimento."

“Art. 24. [...] I - restituição de bens indevidamente subtraídos pelo agressor à ofendida.”

14 “Art. 22 - Constatada a prática de violência doméstica e familiar contra a mulher, nos termos desta Lei, o juiz poderá aplicar, de imediato, ao agressor, em conjunto ou separadamente, as seguintes medidas protetivas de urgência, entre outras [...].”

15 Mais recentemente, a Lei n. 12.641/2018 altera a LMP e cria o tipo penal de descumprimento da MPU. Nova e controversa alteração ocorrida em 2019, pela Lei n. 13.827/2019, autoriza a concessão das medidas protetivas pela autoridade policial. O dissenso interpretativo de que tratamos neste texto é anterior a essas alterações e permanece.

16 Com o entendimento de que os crimes de lesão corporal de natureza leve são de processamento público 
Após a promulgação da Lei, muitas questões cruciais para a efetividade das medidas passaram a ser definidas e disputadas no judiciário, por exemplo, os critérios para aferir a necessidade e o tipo de medida, os requisitos de prova, o tempo de duração da medida e os critérios/situações de sua suspensão. Muitas dessas questões práticas foram traduzidas pelo/a intérprete do direito como um debate sobre a natureza jurídica desse instituto e dependem dessa definição.

Uma das distinções dogmáticas que importa em diferentes consequências para as mulheres está entre os que defendem sua natureza jurídica acessória ao processo e os que afirmam sua independência. No primeiro caso, a medida teria por objetivo garantir a viabilidade do processo e também terminaria com ele, enquanto, na segunda, a proteção da mulher seria um fim em si mesmo.

O processo penal, cuja finalidade é responsabilizar uma pessoa por um crime, só conhece medidas cautelares, que visam a proteger a finalidade do processo. Prisões processuais ou outros tipos de restrição a direitos do acusado não se relacionam com o grau de culpa, mas podem ser decretadas se a liberdade do acusado for um risco ao processo.

Já os teóricos do processo civil entendem a tutela jurisdicional como um meio de proteger pessoas (DINAMARCO, 2017, p. 196) ou bens jurídicos (BUENO, 2014, p. 267) a partir da intervenção judicial. Existem diferentes tipos de tutela jurisdicional. Para a discussão deste texto, importam-nos as chamadas tutelas inibitórias e as tutelas de urgência. As primeiras são cabíveis para obstar a prática de um ato ilícito ou impedir sua continuação, já as tutelas de urgência foram desenvolvidas como instrumentos para diminuir os danos causados pela espera do resultado processual (DINAMARCO, 2017).

No caso das tutelas de urgência, a doutrina processual civil as divide em duas categorias - cautelares e antecipadas. Como explica Dinamarco, as antecipadas "oferecem ao sujeito [sic], desde logo, a fruição integral ou parcial do próprio bem ou situação pela qual litiga” e as cautelares são medidas "destinadas a resguardar o processo em sua eficácia ou na qualidade de seu produto final". Em outras palavras, enquanto as tutelas antecipadas oferecem "situações favoráveis às pessoas na vida comum em relação com outras pessoas ou com os bens”, as cautelares são "medidas de apoio ao processo - para que ele possa produzir resultados úteis e justos - e só indiretamente virão a favorecer o sujeito de direitos" (DINAMARCO, 2017, p. 255). Essas últimas se parecem com as cautelares penais, pois ambas visam à proteção do processo. Isso quer dizer que dependem dele e que se relacionam apenas de forma indireta com a pessoa ou bem jurídico que se tutela com o processo, no caso em discussão, a vida e a integridade física e psíquica das mulheres.

incondicionado, parece-nos que a ameaça é o principal crime recorrente em âmbito doméstico que possui processamento público condicionado à representação. 
Assim, algumas das posições que desatrelam as MPUs da existência de um processo principal afirmam que se trata de tutelas de urgência antecipadas, satisfativas, de natureza cível, o que "permitiria uma substancial ampliação do espectro protetivo da LMP, em comparação à redução de tais medidas ao regime cautelar criminal” (ÁVILA, 2019, p. 22).

Encontramos na doutrina outra forma de classificar as medidas: como tutela inibitória cível. A tutela inibitória teria finalidade preventiva, que "consiste em evitar a violação de direitos e criação ou agravamento de situações desfavoráveis” (DINAMARCO, 2017, p. 247-249). Esse tipo de tutela, estabelecida no ordenamento brasileiro no art. 497, caput e parágrafo único do Código de Processo Civil (CPC), é também autônoma, sendo conferida a partir de ação própria (LOPES e LOPES, 2017). A função das tutelas inibitórias seria então compatível com a enunciada pelas medidas protetivas de urgência: buscam prevenir que a violência ocorra ou se perpetue, e não a repressão do agressor (AMANTINI, 2016, p. 35-36).

Segundo as defensoras Julia Bechara (2010), Nalida Monte e Thais Nader (2017), as medidas protetivas destinadas à tutela da integridade física e psicológica da mulher em situação de violência, tais como as presentes no art. 22, II e III, ostentam natureza de "tutela inibitória”, cujo objetivo é preventivo. Trata-se de tutela jurisdicional preventiva, "voltada para o futuro" (MONTE e NADER, 2017, p. 172), e não de procedimento cautelar, que visa a proteger a finalidade de um processo principal.

As tutelas inibitórias são do ponto de vista prático semelhantes às tutelas de urgência antecipadas, já que são autônomas e não dependem de um processo principal. Na mesma linha de defesa de sua autonomia, mas em outra sistematização dogmática, essas ações foram aproximadas a writs constitucionais que, "como o habeas corpus ou o mandado de segurança, não protegem processos mas direitos fundamentais do indivíduo” (LIMA, 2011, p. 329). ${ }^{17}$

Uma variação do debate é a classificação das medidas como cíveis ou penais. Vistas como cíveis, elas podem ser autônomas (inibitórias e antecipadas) ou não (cautelares), mas, se penais, serão necessariamente cautelares e, portanto, vinculadas ao processo penal. Aqui, a zona de disputa é maior nas medidas que obrigam os agressores e, a partir de 2011, aumentou no tocante a essas modalidades, em virtude da lei que introduziu medidas cautelares penais diferentes da prisão (Lei n. 12.403/2011). Alguns exemplos de cautelares diversas da prisão são a proibição de contato com determinada pessoa ou proibição de acesso a determinados lugares, que também são tipos de medidas protetivas de urgência na LMP (art. 22, III). Outro ponto de contato entre a medida protetiva e a cautelar penal é o fato de ambas terem como sanção ao descumprimento a decretação da prisão, o que fez a doutrina

17 A essa altura, em um texto em que discutimos interpretações que prejudicam a mulher, o uso massivo do universal masculino (sujeito de direito, indivíduo) em textos de doutrina merece ser notado. Afinal, a linguagem é também constitutiva do sistema jurídico. 
chamar a atenção para o fato de que tal consequência não transforma as medidas protetivas em cautelares penais:

O fato de a desobediência às medidas protetivas de urgência ensejar decretação da prisão preventiva não as transforma em cautelares criminais. Trata-se apenas de uma repercussão da tutela cível inibitória no regime cautelar criminal. Isso porque essa desobediência cível documenta um periculum libertatis que gera efeitos para a decretação da prisão preventiva no âmbito criminal [...]. (ÁVILA, 2019, p. 8 da versão on-line)

Note-se que esse debate acontece mesmo diante do $\S 4^{\circ}$ do art. 22 da Lei, que, após descrever as medidas, dispõe que se aplica a elas, no que couber, o disposto no art. 461 do CPC, que trata de ações cíveis que tenham por objeto o cumprimento de obrigação de fazer ou não fazer. ${ }^{18} \mathrm{Ou}$ seja, tal explicitação feita pela lei não evitou a discussão sobre a "natureza" civil ou penal das medidas.

Há também autores que afirmam que as medidas protetivas podem ter natureza e finalidade variadas. Fredie Didier Jr. e Rafael Oliveira (2016) entendem que as medidas protetivas possuem objetivos variados, por vezes visando a proteger a integridade física e a vida da mulher, por outras visando a proteger o processo, "como a ordem para que o réu não se aproxime de testemunhas, por exemplo (art. 22, III, 'a' e 'b', da Lei Maria da Penha)”. Assim, as MPUs seriam "exemplos de tutela provisória de urgência: cautelar (algumas) ou satisfativa (a maior parte)" (DIDIER JR. e OLIVEIRA, 2016).

Uma hipótese explicativa sobre a persistência dessas divergências é a de que o hibridismo da LMP, que envolve medidas cíveis e penais, não seja facilmente absorvido por campos dogmáticos que caminham separados e se definem por oposição há tanto tempo. Isso é acentuado, como discutiremos adiante, pelo processamento da lei pelas varas penais, diante da não criação dos JVDs. Um dos autores do debate se manifesta para aclarar a possibilidade de uma medida cível com repercussão em um processo penal:

[...] (ii) o fato de uma medida cível ter possível repercussão na jurisdição criminal não a transforma necessariamente em uma medida criminal, já que o próprio $\mathrm{CPP}$, em seu art. 92, admite a existência de questões prejudiciais da jurisdição cível a influenciar na jurisdição penal; (iii) quando as medidas protetivas foram criadas, elas não possuíam qualquer simetria com as medidas cautelares criminais [...] e o fato de (apenas) algumas das medidas protetivas terem simetria com posteriores medidas cautelares criminais $\S \S 5^{\circ}$ e $6^{\circ}$ do art. 461 da Lei n. 5.869, de 11 de janeiro de 1973 (Código de Processo Civil).” 
não necessariamente as transforma em medidas cautelares criminais se há um direito fundamental autonomamente tutelável na esfera cível; ademais, a própria LMP previu que elas teriam natureza cível, ao fazer referência, em seu art. 22, § 5 , à aplicação do art. 461 do CPC/1973, que então se referia à tutela inibitória das obrigações de fazer ou não fazer; (iv) a finalidade das medidas protetivas de urgência não é punir o suposto agressor, mas proteger a mulher [...]. (ÁVILA, 2019, p. 5 da versão on-line)

Para além do impulso de sistematização, próprio das discussões dogmáticas, as diferentes classificacões têm consequências concretas para as mulheres e influenciam no âmbito de aplicação das medidas protetivas na medida em que definem o caráter autônomo ou não das medidas.

\section{DISPUTA POR INTERPRETAÇÃO: A APLICAÇÃO DAS MEDIDAS PROTETIVAS NAS INSTÂNCIAS} DO SISTEMA DE JUSTIÇA

O judiciário é o campo de batalha sobre a aplicação e a produção de interpretações sobre as medidas protetivas. Juízes de primeira instância decidem todos os dias a respeito da concessão ou manutenção dessas medidas, e a compreensão que têm acerca de sua natureza jurídica tem repercussão prática relevante. Considerar as medidas autônomas (antecipadas, inibitórias ou assemelhadas ao writ constitucional) gera sua desvinculação do processamento do delito ou de um processo cível que discuta divórcio ou guarda, garantindo uma resposta antecipada e quase imediata à mulher em situação de violência que busca ajuda no sistema de justiça. Nesse caso, a medida pode se manter enquanto houver o risco à mulher, mesmo com o fim do procedimento, pois não está atrelada a ele. Nessa visão, a finalidade da medida - a proteção futura da mulher - não coincide com a finalidade do processo penal - imputar responsabilidade por um ato passado.

Por outro lado, considerar que as medidas protetivas são cautelares (penais ou cíveis) significa vincular sua concessão a um processo judicial principal. Na prática, como os JVDs não têm atuado em causas cíveis, mas apenas criminais (CAMPOS, 2015, p. 399), essa interpretação sedimenta a medida protetiva como uma medida cautelar ao processo penal. Assim sendo, medidas protetivas acabam não sendo concedidas se não houver B.O., inquérito ou processo penal e se extinguem com o fim desses procedimentos. Essa posição é a que tem prevalecido no dia a dia do sistema de justiça. ${ }^{19}$ Como diagnosticam Nalida Monte e Thais Helena Nader, ambas defensoras públicas: firmar essa prática na justiça paulista. 
[...] o entendimento maciço do Judiciário brasileiro é que as medidas são consideradas cautelares preparatórias, ensejando a necessária instauração de processo principal, sob pena de cessar sua eficácia. Desta forma, encerrando-se o inquérito policial ou a ação penal, as medidas protetivas são revogadas de plano, sem qualquer questionamento sobre se ainda há a situação de risco para a mulher. (MONTE e NADER, 2017, p. 170)

Entrevistas com atrizes do sistema de justiça em São Paulo apontaram situações excepcionais em que o juiz ou a juíza do JVD desvincula a protetiva do processo penal. Uma defensora nos relata o trabalho de convencimento realizado junto ao juiz do JVD de São Miguel (Leste II) por profissionais da rede de enfrentamento: ${ }^{20}$

[...] a Rede [de Enfrentamento à Violência Doméstica] [...] conseguiu que o juiz tivesse esse entendimento porque antes ele tinha outro entendimento, ele achava que era requisito o B.O. Foi a Rede que levou os casos práticos e o juiz, tendo esse contato com o que tava acontecendo, dessa negativa de acesso à justiça, que mudou de opinião. ${ }^{21}$

Em conversa com a gerente de um $\mathrm{CDCM}^{22}$ do extremo leste de São Paulo, ela nos conta sobre a força da Rede de Enfrentamento à Violência Doméstica da Zona Leste e a história das negociações sobre a desvinculação entre medida protetiva e B.O.:

[...] acho que a Rede [de Enfrentamento à Violência Doméstica da zona leste], na cidade, é de fato uma das Redes mais antigas. Tem mais de 10 anos. Foi uma mulher do movimento popular que puxou a Rede, que é a Penha, já é falecida, e acho que a Rede foi se fortalecendo justamente porque na Leste também foram tendo outras Casas.

[...] as meninas escreveram um documento falando sobre isso [medidas protetivas] [...] e aí a gente [...] sentou muitas vezes com a Defensoria, com o JVD daqui, com os Defensores que atendiam aqui na região, com o próprio NUDEM [Núcleo de Pomoção e Defesa dos Direitos da Mulher], e falamos sobre isso. E aí a gente conseguiu até uma conversa com

20 A rede de enfrentamento à violência doméstica é formada por diversas organizações (de saúde, assistência social e justiça) que atuam em conjunto na implementação da política de combate à violência que surge a partir da LMP.

21 Entrevista concedida às autoras por defensora pública do Nudem em 20 de julho de 2018.

22 Os Centros de Defesa e Convivência da Mulher, mais conhecidos como CDCM, são serviços da assistência social e consistem em espaços de acolhimento para mulheres em situação de violência. Oferecem atendimento psicológico, jurídico e social, além de serem espaços de convivência, com oficinas e atividades. 
o [...] juiz na ocasião aqui em São Miguel, e ele, com muita dificuldade, entendeu que era possível sim dar a medida de proteção. E a gente também foi fazendo outras conversas, que medida de proteção deve valer enquanto houver violência. "Ah, e como que a gente sabe que não há mais violência?”, precisa falar com as mulheres. São elas quem vão dizer. ${ }^{23}$

Interessante notar como as iniciativas de desvinculação das medidas protetivas das organizações penais partiram, nessa região, das profissionais que atuam cotidianamente com o acolhimento de mulheres em situação de violência. Contudo, o acordo que elas conseguiram firmar nessa região foi pontual e provisório, pois se alterou com a troca dos juízes. Como afirma a defensora do Nudem: "[...] depende muito do juiz ou da juíza que está lá na ponta. Mas claro que se mudar, a gente tem chance de que esse entendimento se perca mesmo". ${ }^{24}$

Essa mesma defensora nos conta que uma colega sua que atua na Vara de Violência de Santo Amaro tem conseguido algumas vitórias, “não com a juíza, mas no Tribunal de Justiça”. Nos casos em que a defensoria recorre, o debate sobre a natureza das protetivas se desloca para a segunda instância.

Realizamos levantamento no TJSP e notamos que esse debate vem sendo realizado por diversas vias processuais, como mandado de segurança, recurso em sentido estrito, apelações criminais e cíveis e agravo de instrumento. ${ }^{25}$ Encontramos no sítio do TJSP 14 acórdãos julgados entre 2015 e 2020, ${ }^{26}$ amostra pouco representativa, mas que ilustra a persistência das disputas em torno dos critérios de concessão de medidas protetivas de urgência nos últimos anos. ${ }^{27}$ Desse total, apenas 5 acórdãos partiam do entendimento de que as medidas podem ser cíveis satisfativas, enquanto nove mencionavam seu caráter cautelar.

Entrevista concedida às autoras em 11 de junho de 2018.

24 Trecho de entrevista concedida às autoras em 20 de julho de 2018 por defensora pública do Nudem.

25 Essa diversidade de instrumentos processuais advém da própria incerteza quanto à natureza das medidas (BECHARA, 2010) e gera grandes dificuldades para a coleta dessas decisões dentro do banco de jurisprudência do Tribunal.

26 Os acórdãos foram encontrados a partir de busca na área "Jurisprudência" no site esaj.tjsp.jus.br a partir das palavras-chave "medidas protetivas e violência doméstica", "medidas protetivas e 11.340/06", "medidas protetivas e satisfativas ou cautelares". A maior parte dos resultados encontrados não eram pertinentes para esta pesquisa e foram descartados. A partir dos acórdãos localizados, encontramos menção a outros acórdãos que não havíamos localizado em nossa busca inicial. O recorte temporal a partir de 2015 reflete o início desta pesquisa e o momento em que tivemos acesso à disputa em primeira instância. Não tínhamos interesse em coletar dados longitudinalmente, mas sim retratar o estado do debate nas instâncias superiores.

27 Foram encontrados mais acórdãos que discutiam concessão ou não de medidas protetivas, porém selecionamos aqueles que tratavam mais especificamente da discussão de natureza das MPUs. 
Como exemplo de acórdão em que as MPUs são entendidas como cautelares, selecionamos a seguinte ementa:

As Medidas Protetivas de Urgência previstas na Lei n. 11.340/06 não possuem caráter satisfativo, mas meramente processual, uma vez que, diversamente das medidas cautelares previstas na legislação processual civil, visam apenas a oferecer proteção acauteladora imediata à vítima das agressões. (SÃO PAULO, 2020)

Em outros acórdãos, encontramos o entendimento de que a manutenção das medidas protetivas por período indeterminado seria uma "ofensa a direitos individuais e garantias fundamentais [...], como a legalidade, a proporcionalidade e, em última análise, a dignidade da pessoa humana". ${ }^{28}$ Uma variação deste é a de que a desvinculação das medidas protetivas de uma ação principal seria "atribuir indevido efeito de pena sem prazo determinado ao provimento jurisdicional concessivo". ${ }^{29} \mathrm{O}$ argumento garantista ou de segurança jurídica, aparentemente neutro, escolhe uma das realidades para se preocupar: o foco está na posição do homem e não na segurança da mulher. Uma de nossas entrevistadas interpreta esse entendimento como decorrente de outra falha na aplicação das medidas: o fato de que seu cumprimento não é fiscalizado, o juiz não volta a checar se o risco à mulher persiste ou não, então se sente mais confortável ao saber que a medida acaba com o fim do procedimento penal. Contudo, a falha no sistema não deveria ser usada em prejuízo da proteção da mulher.

No polo oposto, encontramos algumas decisões que entendem a possibilidade de se aplicar as MPUs no âmbito cível (independentemente de um processo penal) e com o objetivo de proteger a integridade física e psicológica da mulher. ${ }^{30}$ As decisões nesse sentido costumam remeter aos precedentes do STJ, de que falaremos adiante. Nesse grupo de acórdãos, também apareceu o argumento que valoriza a palavra da vítima para aferir a situação de perigo: "[t]ratando-se de violência doméstica, as declarações da ofendida assumem especial relevância, a justificar a aplicação das seguintes medidas protetivas de urgência”. ${ }^{31}$

Houve tentativas de disputar esse entendimento em espaços que tivessem algum potencial de uniformização. Uma das arenas em que isso se deu foi no Fórum Nacional de Juízas e Juízes de Violência Doméstica e Familiar contra a Mulher (Fonavid), criado em 2009 em uma parceria entre o Ministério da Justiça, a Secretaria de Política para as Mulheres e o Conselho

Retirado de São Paulo (2019b).

29 Retirado de São Paulo (2016).

30 São Paulo (2019a).

31 Retirado de São Paulo (2017b). 
Nacional de Justiça (CNJ), com o objetivo de "manter um espaço permanente de discussões sobre o tema onde os participantes compartilham experiências, definem a uniformização dos procedimentos, decisões dos juizados e varas especializadas em violência doméstica e familiar contra a mulher sob a perspectiva da efetividade jurídica e o aperfeiçoamento dos magistrados e equipes multidisciplinares". 32

Os enunciados acordados nessa reunião de juízes, embora não tenham efeito vinculante, expressam diretrizes práticas para a atuação desses magistrados. Até 2016, ano do VIII Fonavid, o enunciado n. 5 afirmava que a competência dos Juizados de Violência Doméstica e Familiar contra a Mulher estaria condicionada à existência de notícia-crime ou representação criminal da vítima. Tal entendimento foi revogado com a aprovação do enunciado n. 37 , segundo o qual "a concessão da medida protetiva de urgência não está condicionada à existência de fato que configure, em tese, ilícito penal”. Segundo uma juíza que acompanhou essa mudança de entendimento, "teve resistência, tem ainda. Tanto que tem pessoas do Fonavid que entendem diversamente", ${ }^{33}$ o que demonstra que, apesar de persuasiva, a mudança dos enunciados não significa uma mudança na mentalidade judicial no primeiro grau.

Da mesma forma, dentro da Defensoria Pública essa tese também se tornou uma diretriz de atuação, como explica uma das defensoras entrevistadas para esta pesquisa:

[...] tem uma tese, ela foi escrita por uma Defensora que atua na Vara deViolência de Santo Amaro, elas têm conseguido lá algumas vitórias, não com a juíza, mas no Tribunal de Justiça, mas a tese na Defensoria não é vinculante, é uma orientação para os defensores. ${ }^{\mathbf{3 4}}$

Trata-se de tese aprovada no VIII Encontro de Defensores Públicos de São Paulo, que aconteceu em 2015, em que foram aprovadas oito teses jurídicas que devem pautar a atuação dos defensores de cada matéria. A autora da tese foi a defensora Nalida Coelho Monte, ${ }^{35}$ e o texto aprovado determina que as medidas protetivas da LMP "não exigem, para sua concessão e manutenção, a existência de Boletim de Ocorrência, representação criminal ou procedimento criminal". 36

Fonavid. Disponível em: https: / / www.cnj.jus.br/programas-e-acoes/violencia-contra-a-mulher/forum-nacionalde-juizes-de-violencia-domestica-e-familiar-contra-a-mulher-fonavid/. Acesso em: 18 nov. 2020. Mais informações sobre o Fonavid podem ser encontradas no site: http://www.amb.com.br/fonavid/. Acesso em: 18 nov. 2020. São Paulo.

34 Entrevista concedida às autoras em 24 de junho de 2016 por defensora pública do Nudem.

35 Autora de texto de doutrina que citamos na seção anterior. 
Esse conflito interpretativo chegou ao STJ, que se pronunciou em 2014 e afirmou a autonomia das medidas no Recurso Especial n. 1.419.421/GO, relatado pelo Ministro Luis Felipe Salomão. O caso concreto teve origem no pedido de medida protetiva feito por uma mulher contra seu filho, de quem vinha sofrendo agressões, que haviam escalado de xingamentos a ameaças de morte. Por essa razão, ela recorreu ao art. 22 da LMP, pedindo à Justiça a proibição de que o filho se aproximasse dela e de seus outros filhos ou mantivesse contato por quaisquer meios de comunicação, e a suspensão da posse ou restrição do porte de armas. A demanda central do caso é a de que uma mulher pudesse se valer das medidas protetivas sem que houvesse uma ação penal em curso. Em primeira instância, o processo foi extinto sem julgamento do mérito, com base no entendimento de que as medidas protetivas de urgência “têm natureza processual penal e sempre instrumentais ao processo-crime". Em grau de apelação, a sentença foi cassada, afirmando-se que as medidas têm natureza cível, com caráter satisfativo e autônomas. O STJ então definiu que as medidas protetivas podem ser "pleiteadas de forma autônoma para fins de cessação ou acautelamento de violência doméstica contra a mulher, independentemente da existência, presente ou potencial, de processo-crime ou ação principal contra o suposto agressor”. ${ }^{37}$ A Quarta Turma entendeu que as medidas protetivas têm natureza "cautelar cível satisfativa”, "não se exigindo instrumentalidade a outro processo cível ou criminal, haja vista que não se busca necessariamente garantir a eficácia prática da tutela principal". ${ }^{38}$ Embora a nomenclatura usada pelo STJ seja confusa - ao conjugar as expressões "cautelar" e "satisfativa" -, não houve dúvida sobre a afirmação de seu caráter autônomo.

Essa decisão não evitou que outra Turma da mesma Corte chegasse a entendimentos parcialmente divergentes, no sentido de que algumas das medidas protetivas possuiriam caráter penal, como a suspensão de posse de arma ou proibição de determinadas condutas (art. 22, I e III). ${ }^{39}$ Em 2017, contudo, a Quinta Turma julgou agravo regimental sobre o mesmo tema, voltando a entender que as medidas protetivas possuem natureza jurídica inibitória ${ }^{40}$ e são independentes dos autos principais, "garantindo o caráter satisfativo de proteção às vítimas buscada pela norma”. 41

Defensores Públicos, 16 dez. 2015. Disponível em: https://www.apadep.org.br/noticias/viii-encontro-dedefensores-publicos-aprova-oito-novas-teses-institucionais/. Acesso em: 31 out. 2018.

Brasil (2014a).

38 Brasil (2014a).

39 A título de exemplo: Brasil (2017b) e Brasil (2018).

40 Notamos que essa decisão dialoga com a de 2014, mas percebe-se uma mudança de vocabulário: na primeira, as medidas são classificadas como cíveis satisfativas e, na segunda, inibitórias.

Brasil (2017a). 
Contudo, embora tenham potencial persuasivo, nem o enunciado do Fonavid, nem as decisões do STJ são vinculantes, ainda que essas últimas devessem ser levadas em consideração pelas instâncias inferiores, já que vêm de instância revisora. Na prática, mesmo após as decisões do STJ, tem prevalecido na primeira instância a interpretação das MPUs como acessórias ao processo penal. Tal diagnóstico foi confirmado pelas entrevistas realizadas entre os anos de 2015 e 2018 com profissionais que atuam em diversas etapas do processamento de demandas ligadas à violência doméstica.

Segundo as defensoras que entrevistamos, como muitos casos se encerram na primeira ou segunda instâncias, sem recurso, decisões que apontam para o entendimento oposto ao do STJ acabam gerando efeitos, sem maiores questionamentos. Além disso, ainda que haja chances de reverter tal posição mediante recursos, a falta de uniformização do entendimento em primeira instância significa demora no acesso à justiça, o que no caso das situações de ameaças ou violência que ensejam a concessão da medida pode significar que a justiça chegue tarde demais. Na prática, o dissenso em primeira instância é suficiente para negar ou fazer tardar o acesso da mulher ao seu direito à proteção do Estado.

Nesse sentido, a imposição via interpretação jurídica de condições não previstas na lei para a concessão da medida protetiva é mais do que um debate doutrinário: trata-se de uma escolha político-jurídica que impõe barreiras no acesso à justiça para as mulheres que buscam os caminhos oferecidos pelo direito para verem-se livres da violência o quanto antes.

\section{A pergunta das mulheres: as consequências concretas da classificaÇão} DOGMÁTICA DAS MEDIDAS PROTETIVAS DE URGÊNCIA

Se a LMP propõe uma compreensiva política pública de proteção à mulher, a MPU é um de seus mecanismos centrais, pois cria um remédio jurídico inédito que permite a intervenção imediata do Estado para proteger a mulher e retirá-la do ciclo de violência. Assim, o que está em jogo nas interpretações que guiam a aplicação desse instituto é o acesso da mulher a um mecanismo de tutela a seus direitos fundamentais. Do ponto de vista das mulheres, e considerando a diversidade desse grupo, marcado por intersecções estruturais de raça e classe, dentre outras, interpretacões jurídicas podem facilitar ou dificultar a garantia de seus direitos; levar ou não em consideração suas realidades.

Propomos aqui olhar a questão com tal diferença de ênfase: colocar em primeiro plano as consequências concretas de determinadas interpretações jurídicas na vida das mulheres e especialmente nos diferentes grupos de mulheres. Fazemos aqui a "pergunta das mulheres”, método proposto por Bartlett a fim de identificar e desafiar os elementos da doutrina jurídica que colocam as mulheres ou os grupos excluídos em posições de desvantagem. O pressuposto do método é o de que as soluções jurídicas são respostas pragmáticas a dilemas concretos da vida e não escolhas estáticas ou abstratas e, por isso, utiliza como uma de suas fontes insights e perspectivas de experiências pessoais (BARTLETT, 1990, p. 831). 
Ao fazer a "pergunta das mulheres" para investigar as consequências concretas de um debate dogmático aparentemente abstrato e classificatório, chamamos atenção para o fato de que neutralidade e abstração são um mito e de que todas as decisões no direito têm efeitos concretos, encarnados na realidade. A questão é escolher apenas qual realidade estamos considerando e decidindo privilegiar.

Para avançar nesse exercício, de dogmática jurídica encarnada na realidade, esta seção está baseada em situações e dilemas concretos coletados a partir de percepções de operadoras do sistema - defensoras, promotoras, juízas, advogadas e profissionais da rede de atendimento, pessoas que diariamente atendem mulheres em situação de violência. Essa investigação deve avançar para ouvir as próprias mulheres vítimas de violência; contudo, para os fins deste artigo, esse conjunto de entrevistas já foi capaz de revelar como as categorias jurídicas utilizadas para definir as medidas protetivas de urgência têm implicações de gênero e sobrecarregam especialmente mulheres atravessadas por marcadores de raça e classe.

A interpretação da medida protetiva como medida cautelar revelou-se problemática por uma série de razões, que se interconectam. Apenas para fins desta exposição, agrupamos as consequências dessa interpretação para as mulheres nos seguintes grupos de problemas: deixa a mulher desprotegida, cria obstáculo no acesso a direitos, tem potencial revitimizador, desconsidera outras portas de acesso à rede de enfrentamento à violência e fere seu direito de escolha.

\section{a) O ENTENDIMENTO DA MPU COMO MEDIDA CAUTELAR DEIXA A MULHER DESPROTEGIDA}

O entendimento coloca em xeque a própria finalidade das medidas, que foram idealizadas como instrumentos de proteção para a mulher em situação de vulnerabilidade, e não para a garantia do andamento do processo criminal. Esse entendimento nega proteção a mulheres que não fazem o B. O., que se retratam da representação (nos casos de crimes de ação pública condicionada), que não buscam advogado para ingressar com ação penal (em casos de crimes contra a honra), além de casos em que a ameaça existe mas não está tipificada como crime, como a violência psicológica ou o stalking (PIRES, 2011, p. 151).

A vinculação do caráter penal às medidas protetivas também justificou a sua revogação em razão do arquivamento de inquérito policial, ou do desfecho da ação penal, independentemente da verificação da persistência ou não do risco à mulher. ${ }^{42}$ Uma das juízas entrevistadas descreve essa dinâmica:

Eu trato aqui as medidas protetivas como uma cautelar acessória a um principal, que é o processo criminal. [...] Na medida em que o processo criminal é extinto, eu acabo

42 A exemplo de São Paulo (2018) e de São Paulo (2019b). 
também extinguindo a medida protetiva, então ela só tem validade enquanto vigora o processo penal para que não haja uma restrição ao direito do réu eternamente. ${ }^{43}$

Segundo uma de nossas entrevistadas, "a medida cai quando não necessariamente cai o risco à vida, a violência”, e isso seria “perverso", pois a mulher tem que fazer todo o movimento de voltar a pedir a medida e justificar a sua necessidade novamente (advogada de serviço especializado). Isso também é mencionado por outra juíza entrevistada, com entendimento oposto à que citamos anteriormente:

Não tem prazo para a medida protetiva. Não tá escrito em lugar nenhum que tem prazo, ela tem que durar enquanto for necessária a proteção da vítima. Na minha interpretação, e não sou a única, têm teóricas que falam isso também, a medida protetiva é uma cautelar satisfativa de natureza híbrida. Qualquer cautelar satisfativa não tem prazo de validade, isso é uma criação. Enquanto ela é necessária para a proteção da vítima, ela tem que viger. [...] Então fixar prazo de vigência, na minha concepção, traz duas problemáticas: primeiro, o necessário e contínuo uso do sistema de justiça para que a aplicação seja conseguida, porque a cada nova intervenção, a cada nova agressão, a cada novo descumprimento de protetiva, se ela tem um prazo de validade, você vai precisar pedir de novo. Então acho que você acaba acionando o sistema desnecessariamente porque, se ela não tem prazo de validade, você só olha e se preocupa com o cumprimento e não com a agressão. O segundo problema é que você deixa a pessoa sem proteção porque se parte do pressuposto que a violação de direito tem prazo estabelecido e não violência de gênero a gente sabe que não tem. ${ }^{44}$

Na visão expressa por uma promotora de justiça adepta da tese da autonomia, a medida “dura até a hora que essa mulher precisa de proteção". Ela narra situação concreta que explicita as consequências desse problema - a mulher fica desprotegida, mesmo após a sentença condenatória do réu:

Outra coisa: deu a sentença. Se ela for, também, de natureza penal e acessória, como são todas as medidas cautelares, deu a sentença, ele é condenado a dois meses de pena em regime aberto, porque não dá para dar fechado, ele estava preso cautelarmente por ter descumprido uma protetiva e ele sai solto do fórum. De que adiantou o processo para essa mulher se ela ainda está em situação de violência? A partir do momento em

43 Entrevista concedida às autoras em 5 de julho de 2016, por juíza de JVD da zona oeste.

44 Entrevista concedida às autoras em 28 de agosto de 2018. 
que você dá a sentença, a medida principal substitui a acessória. E aí, fica como? Você está protegendo essa mulher? De que adianta obter uma condenação ${ }^{45}$

Esses relatos nos mostram a insuficiência das respostas do processo penal para efetivar a proteção da mulher e, como consequência, a importância de preservar a autonomia das medidas protetivas em face do processo criminal.

O processo penal, que gira em torno de um ato tipificado como crime, produz uma redução da realidade das mulheres e não consegue captar a situação de violência a que estão submetidas. Ao funcionar como filtro para as medidas protetivas, há um desvirtuamento da lógica das protetivas, que acabam se distanciando das necessidades da mulher, como explica uma das advogadas entrevistadas:

[...] escutar essa situação de violência e tentar entender qual é o socorro que ela está pedindo e tentar pensar qual é a proteção e nesse sentido, para mim é isso: a relação não está entre crime e proteção, a relação está entre a violência, os efeitos da violência e a proteção. Para uma mulher, talvez vá funcionar um afastamento do lar, para outra talvez vá funcionar ir para um abrigo, para outra vai funcionar simplesmente o sigilo da matrícula do filho dela. [...] Então para mim a relação está aí, a gente precisa escutar a singularidade de cada mulher, de cada situação. [...] Em síntese, eu acho que medida protetiva tem que estar desvinculada de boletim de ocorrência, acho que ela tem que estar vinculada ao histórico da violência, aos efeitos da violência e ao que a mulher deseja e ao processo autônomo da mulher sobre o que ela quer fazer sobre a vida dela e existe tese jurídica para isso. ${ }^{46}$

\section{b) Criação de ObSTÁculos No ACESSO A diReITOS}

A interpretação da medida como vinculada ao processo, como vimos, cria requisitos que não estão na lei para que a mulher acesse seu direito à tutela protetiva. No entender de uma promotora entrevistada, "a Lei Maria da Penha não fala que precisa ser concomitantemente com andamento processual, que ela tem que denunciar, então por que você vai criar uma restrição se a própria Lei não prevê? Você não pode criar uma restrição que não está prevista em lei”. ${ }^{47}$ Ou seja, cria-se, no âmbito da aplicação, independentemente de previsão legal, uma restrição que prejudica a mulher.

Entrevista concedida às autoras em 24 de junho de 2016 por promotora atuante no Gevid.

Entrevista concedida às autoras em 20 de maio de 2016 por advogada de CDCM.

Idem à nota 45. 
O entendimento também é responsável por outro tipo de obstáculo ao acesso a direitos: para conseguir proteção, a mulher necessariamente tem que acessar dois serviços diferentes, a delegacia e o sistema de justiça. ${ }^{48}$ Porém, o problema não é apenas o do caminho mais longo. A literatura sobre atendimento a mulheres em situação de violência aponta diversas críticas às delegacias - da mulher ou não - no atendimento a vítimas de violência doméstica, seja pela falta de recursos, falta de sensibilidade dos profissionais, falta de articulação entre a delegacia e os demais serviços, entre outros (LINS, 2014; CAMPOS, 2015). Como veremos, a seguir, a delegacia é tanto obstáculo como ambiente revitimizador.

Além disso, o entendimento da protetiva como uma cautelar penal dificulta a concessão da medida, já que aumenta a exigência probatória. Sendo uma medida cautelar penal, há de se provar também a materialidade do crime, o que desvia substancialmente da análise da segurança da mulher e coloca em cena debates sobre a qualidade do relato presente no B.O. ${ }^{49}$ a qualidade de mensagens ameaçadoras anexadas aos autos ou a existência de testemunhos. ${ }^{\mathbf{5 0}}$ Uma de nossas entrevistadas conta, por exemplo, a dificuldade de se obter prova testemunhal em casos de violência doméstica, situação que se agrava em mulheres pobres e periféricas:

Muito difícil [para essa mulher ter testemunhas], não só por uma questão [...] concreta, material de que a violência ocorre em casa, entre quatro paredes, mas porque as pessoas não querem se envolver porque o território em que elas vivem é o mesmo. Quem vive em outro território é o Juiz, Defensor e Promotor, [...]. As pessoas não querem se envolver [...] Se o Juiz pedisse para escutar aquela mulher e fizesse perguntas para tentar entender aquele histórico, é muito rico. E não, o que ele valoriza é a palavra dessa testemunha. Não estou desprezando que tenha que ter testemunha, mas podia ser diferente, podia se pensar um pouco nessa oralidade, na valorização desse relato para o pedido de medida protetiva. ${ }^{\mathbf{5 1}}$

48 Isso mudou com a Lei n. 13.827/2019, que autoriza que a medida seja decretada pela autoridade policial, mas ainda não sabemos o quanto.

49 A exemplo do Mandado de Segurança n. 2146796-33.2017.8.26.0000, julgado em 2017, em que os Desembargadores entendem que: "A única comprovação da eventual conduta criminosa é o boletim de ocorrência [...], onde consta o relato da vítima que declarou ser ameaçada de morte constantemente [...]. Ocorre que as alegações são vagas, sem qualquer descrição detalhada das condutas ilícitas supostamente perpetradas pelo acusado”. Cf. São Paulo (2017c).

50 A exemplo do Mandado de Segurança n. 2014212-02.2017.8.26.0000, julgado em 2017, em que os Desembargadores decidem que: "A eventual ameaça noticiada pela vítima ocorrida através de mensagem em seu aparelho celular não tem o condão de comprovar a data ou sequer se foi emitida por seu ex-companheiro”. Cf. São Paulo (2017a).

51 Trechos de entrevista concedida às autoras em 20 de maio de 2016 por advogada de CDCM. 
Além do dado em si sobre a dificuldade de obtenção de testemunhos, muitas vezes os procedimentos penais são mal instruídos por falha das próprias instituições do sistema de justiça, e, nesses casos, o ônus é da mulher. A insuficiência de servidores nas delegacias, por exemplo, tem sido a justificativa para uma prática em que o registro dos B.O. e a tomada do depoimento das vítimas e/ou testemunhas não se efetuem no mesmo momento. Muitas vezes nem vítima, nem testemunhas retornam à delegacia, o que dificulta e às vezes até mesmo invializa a continuidade do inquérito policial (SENADO FEDERAL, 2013, p. 49). Nesse caso, o mau funcionamento das delegacias é que determina o fim do caso criminal, que por sua vez atinge em cheio a proteção da mulher, já que o destino da investigação criminal é decisivo para o de sua medida protetiva.

Trataremos disso adiante, mas vale a pena também observar aqui que a obrigatoriedade de acionar o sistema de justiça criminal significa obstáculo intransponível para algumas mulheres que não desejam denunciar o agressor. Como destaca uma defensora do Nudem:

[...] condicionar que a mulher faça um B. O. para ter o acesso à protetiva, na verdade, é vedar o acesso à justiça para essa mulher porque nem sempre ela vai querer que o companheiro, que o filho, enfim, o autor ou autora da violência seja processado criminalmente. O que a gente, na nossa prática, tendo esse contato com as mulheres, vê é que elas querem uma vida sem violência. ${ }^{\mathbf{2}}$

\section{c) Potencial revitimizador}

Um terceiro motivo pelo qual a via criminal pode ser prejudicial para as mulheres é pelo seu potencial revitimizador. Fazer com que a mulher obrigatoriamente acione o sistema penal é, segundo uma das entrevistas, fazê-la percorrer a "via crucis que a gente já sabe": "de recontar a história um milhão de vezes e de muitas vezes ser humilhada dentro da delegacia; de muitas vezes ter sua voz desconsiderada no inquérito policial”. ${ }^{53}$

A vinculação das medidas ao procedimento penal torna-se ainda mais custosa para as mulheres diante da insuficiente implementação das delegacias da mulher, que cobre apenas uma pequena parcela dos municípios do país, como dificuldades para registrar ocorrências, dificuldade de acesso a informação sobre direitos e "constantes desrespeitos a mulheres durantes [sic] atendimentos em delegacias” (SENADO FEDERAL, 2013, p. 429; p. 621).

Para dar concretude ao potencial revitimizador da exigência do B.O. para que a mulher acesse a proteção pelo sistema de justiça, trazemos aqui dois relatos de nossas entrevistadas:

52 Trechos de entrevista concedida às autoras em 20 de julho de 2018 por defensora pública do Nudem.

53 Trechos de entrevista concedida às autoras em 14 de maio de 2016 por advogada vinculada ao Cladem. 
[...] a gente tem muita denúncia relacionada às Delegacias, não tanto às varas [...]. É muito comum receber denúncia do atendimento, do acolhimento dessa mulher. Em geral, a gente já recebeu denúncia, por exemplo, onde o Delegado cumprimenta, aperta a mão do agressor e deixa a mulher sentada numa cadeira, de lado, dentro da sala e fica ouvindo o agressor. Então assim, [...] em cidades muito pequenas as pessoas se conhecem, o Delegado, em geral, vai conhecer esse homem e, em geral, isso vai influenciar na condução daquele inquérito. ${ }^{\mathbf{5 4}}$

Quando você me pergunta se na Delegacia um profissional é capacitado, eu vou dizer que é porque ele é capacitado justamente para não selecionar a vida das mulheres pobres, negras como um bem a ser protegido, a ser tutelado como é a propriedade privada, como é a moral do trabalho quando se criminaliza o tráfico de drogas. Então ele é super bem capacitado, ele corresponde à lógica de justiça do sistema de justiça criminal. ${ }^{\mathbf{5}}$

A vinculação das medidas protetivas ao processo penal amplifica, inclusive para os aspectos não penais da lei - como as medidas protetivas -, os problemas do funcionamento das instituições penais, marcado não apenas pela falta de tratamento adequado a vítimas, mas especialmente pelos estereótipos de gênero mobilizados por seus atores (MACHADO et al., 2015).

\section{d) DESCONSIDERAÇÃO DE OUTRAS PORTAS DE ACESSO À REDE DE ENFRENTAMENTO À VIOLÊNCIA} A exigência do B. O. para concessão de medidas protetivas também tem como consequência a desconsideração de outras portas de acesso, além da delegacia, à rede de enfrentamento à violência. Assim, o problema não é apenas a provável humilhação que a vítima de violência sofrerá na delegacia, mas o fato de que essa obrigatoriedade representa, digamos assim, um custo de oportunidade, já que outras instituições estão mais bem equipadas para atendê-la. Como afirma defensora pública do Nudem:

[...] a ideia, quando a gente fala da desnecessidade do B.O., é também trabalhar que outras portas de entrada sejam acessadas por ela [mulher em situação de violência], que ela compreenda que ela não precisa ir em uma Delegacia para dar os encaminhamentos em uma situação, para sair do ciclo de violência.

Ela pode ir na Defensoria, ela pode ir no Ministério Público, ela pode ir em um Centro de Referência da Mulher, ela pode ir num Centro de Convivência da Mulher, enfim. Acho

54 Trecho de entrevista concedida às autoras em 5 de julho de 2016, por juíza de JVD da zona oeste.

Trechos de entrevista concedida às autoras em 20 de maio de 2016 por advogada de CDCM. 
que a grande sacada e a grande importância de desvincular do B.O. é também possibilitar outras portas de entrada. Porque hoje, quando você vincula ao B. O., você tem que fazer o pedido da protetiva na Delegacia. [...] Então eu entendo que, na verdade, isso dá um acesso maior à justiça para as mulheres. ${ }^{56}$

A principal função de um B. O. é iniciar o inquérito policial, que visa à investigação do ocorrido para subsidiar eventual punição do acusado. Quando a mulher em situação de violência acessa outras portas, ela também recebe outros encaminhamentos que podem ser mais importantes para seu contexto de vulnerabilidade. Algumas defensoras entendem que o primeiro atendimento poderia ser feito pela Defensoria. ${ }^{57}$ Outra opção é que a entrada seja a própria rede de atendimento, que, ainda que com deficiências de implantação, é mais capacitada do que as delegacias. Como indica entrevista com gerente de serviço especializado no extremo leste de São Paulo:

Na ocasião antes disso a gente já estava fazendo uma pesquisa, uma pesquisa simples, que era o contato com as mulheres que tinham ido na Delegacia [...] para dizer: "Olha, as mulheres são muito mal atendidas nas Delegacias e, se elas pudessem não retornar, elas não retornariam”. Então a gente chegou a fazer conversas com Delegadas. A conversa era no sentido de que: "Olha, a gente só quer que a Delegacia faça o papel dela, que não dê conselhos, que só registre o Boletim de Ocorrência, oriente o que tiver que orientar e encaminhe para a Rede de atendimento", tentando fazer com que a Delegacia não seja mais porta de entrada dessas mulheres, que sejam as Casas e que a partir daqui elas recebam todo tipo de orientação e suporte. ${ }^{58}$

A delegacia, nesse sentido, poderia ser acessada em uma etapa posterior, quando a vítima já tiver recebido assistência e já tiver sido orientada quanto às suas opções, já que o caminho punitivo é apenas um entre os possíveis para a reestruturação da vida após a violência. O depoimento da advogada atuante em CDCM dá concretude às necessidades de suporte que uma mulher vítima de violência doméstica tem em seu primeiro atendimento:

56 Entrevista concedida pela defensora às autoras em 20 de julho de 2018.

57 “[...] A nossa expectativa é de transferir... que a mulher vá até a Defensoria para poder ser acolhida. A gente não nutre expectativas com a porta de entrada pela Delegacia. Cada vez menos, na verdade. A história está mostrando isso. Por que na Defensoria, em tese, ela já vai conseguir ter o acolhimento integral das questões que dizem respeito à violência.”

58 Entrevista concedida às autoras em 11 de junho de 2018 por gerente de CDCM. 
Desde que eu cheguei aqui, faz mais de um ano e meio, sempre o que eu escuto das mulheres nunca é uma demanda de criminalização, elas nunca trazem "Eu quero registrar uma ocorrência", "Eu quero que ele seja processado" ou "Eu quero que ele seja punido", é sempre um pedido de socorro, que passa tanto por um socorro de ser escutada, uma demanda de ser escutada - e não é que elas não falam sobre isso nos seus círculos, elas falam, mas é diferente a escuta que ela vai ter aqui, que é um espaço que está predisposto a entender que ela está em uma situação de violência, em que ela vai encontrar algum amparo - e outra demanda de socorro que é de proteção, concretamente - "O que eu faço? Ele está em casa”, etc. E aí eu acho que proteção e criminalização são duas coisas bastante distintas. ${ }^{59}$

Ao serem atendidas em um serviço multissetorial, as mulheres recebem atendimento às suas demandas específicas, além de orientação jurídica especializada, o que permite que façam escolhas mais informadas sobre o processo penal. Investir para que espaços como esses sejam também portas de entrada prioritárias é consistente com as conclusões dos estudos conduzidos pela Organização Pan-Americana da Saúde, mapeando o caminho percorrido pelas mulheres para romper com a violência, também chamado de a "rota crítica".

Esses estudos mostraram que as decisões das mulheres de buscar ajuda se relacionam às suas percepções de assistência institucional (SAGOT, 2000), e muitas mulheres que efetivamente procuraram ajuda não encontram proteção, enfrentaram interações difíceis e desencorajadoras com funcionários públicos, combinadas com a ausência de serviços de apoio. Toda a ideia da "rede de atendimento" presente na LMP visava justamente a oferecer diversos pontos de entrada à mulher no sistema (BRASIL, 2011, p. 30), e uma interpretação restritiva da Lei fere seu propósito.

\section{Fere O DiReito de ESCOLHA dA MULher}

Além dos efeitos que impactam diretamente na proteção da mulher pelo sistema de justiça, o debate sobre a natureza das medidas protetivas também se reflete no já diminuto espaço de escolha da mulher. Como vimos, uma das consequências da vedação da aplicação da Lei n. 9.099 aos casos de violência doméstica foi transformar as lesões corporais de natureza leve - em geral tratadas como ação penal condicionada à vontade da vítima em seguir com o processo penal ${ }^{60}$ - em crime de iniciativa pública incondicionada. Isso quer dizer que a vítima

59 Trechos de entrevista concedida às autoras em 20 de maio de 2016 por advogada de CDCM.

60 A lesão corporal leve é considerada crime de menor potencial ofensivo por ter pena máxima de 1 (um) ano, conforme art. 129 do CP. 
de lesões corporais no âmbito doméstico já não tem a opção de escolher se quer ou não processar criminalmente o agressor; o sistema penal se move independentemente da vontade da vítima e tampouco se aplicam as alternativas ao processo penal - entendimento que foi confirmado pelo Supremo Tribunal Federal (STF) no julgamento da ADI n. 4.424 (BRASIL, 2014b).

Contudo, há outros crimes que não seguem essa dinâmica. Por exemplo, xingamentos ou exposição indevida da mulher que caracterizem injúria ou difamação são processados pela via da ação penal privada - ou seja, a mulher deve, se quiser, iniciar a ação penal. Mais relevante ainda em casos envolvendo a segurança da mulher é o crime de ameaça, que demanda a autorização ("representação") da vítima para que o agressor seja processado criminalmente. Nesses casos, o entendimento que vincula a protetiva ao caso penal tem como resultado a impossibilidade de conceder a medida para a mulher vítima de crime contra a honra ou ameaça que, exercendo o espaço dado pela lei, escolhe não acionar a via penal. Apenas a mulher que decide fazer o B.O., representar ou iniciar ação penal merece proteção do sistema.

A situação concreta narrada por uma promotora que atua na área permite dimensionar a gravidade dessa escolha, que podemos descrever como "a lei só protege a mulher que acusa":

Por exemplo, a mulher que não vai na Delegacia, que não quer processar o marido, não quer que ele vá preso, não quer que ele seja processado, mas precisa de uma proteção, quer tirar ele de casa. É uma medida protetiva. Se ela for acessória, você acha que ela vai conseguir? Se não tem o principal, porque o principal seria o processo penal e elas teriam uma medida cautelar de natureza penal, acessória. Se não tem o principal, não tem o acessório. Então eu defendo a autonomia. ${ }^{61}$

A questão das protetivas recoloca de alguma maneira, embora em limites mais estreitos, o debate sobre a adequação da solução penal para os casos de violência e seus diferentes impactos em diferentes grupos de mulheres. Em entrevista, uma defensora pública expõe diferentes situações em que o direito penal traz repercussões negativas para a vida das mulheres, que ponderam: "bom, se eu processar meu companheiro ele pode ser preso, se ele for preso ele vai deixar de pagar a pensão"; ou ainda caso em que

a mulher estava em território em que tinha crime organizado, para ela levar a questão para o lado criminal era uma problemática ou o filho tem uma situação de drogadição, então ela não quer um processo criminal, ela quer um tratamento, mas também, ao mesmo tempo, não quer mais contato com ele. ${ }^{62}$

61 Entrevista concedida às autoras em 24 de junho de 2016 por promotora atuante no Gevid.

62 Trechos de entrevista concedida por defensora pública do Nudem às autoras em 20 de julho de 2018. 
Outra defensora nos conta, ainda, sobre outro tipo de impacto negativo de um sistema que impõe a via penal à mulher - além de desprotegida, acaba sendo culpabilizada:

As mulheres não buscam o Judiciário ou mesmo esses acolhimentos por conta da ação criminal em si, elas buscam mais pelas medidas protetivas, pra acabar com aquele conflito familiar [...]. E, muitas vezes, o próprio Direito Penal acaba tendo efeitos negativos sobre a mulher, que são aqueles casos em que, por exemplo, a mulher fez a denúncia, prestou queixa, tudo direitinho e aí quando chega na audiência ela não quer mais continuar com a demanda. E aí [...], muitas vezes o promotor ou o juiz acabam falando "ah, mas outra hora você falou que era uma coisa, agora você tá desmentindo" e aí pressionam a mulher falando que é denunciação caluniosa e a mulher, de vítima, pode virar ré ali. Então acho que tem um efeito perverso para as próprias mulheres esse sistema que as obriga, a todo custo, a seguir com o processo criminal. ${ }^{63}$

Esse entendimento limita sobremaneira tanto a proteção como a autonomia da mulher: a mulher que não quer acusar não recebe a protetiva, e a mulher que precisa da protetiva não tem opção de não acionar o sistema penal, sendo-lhe negado o direito de escolha. E isso se dá no caso em que a própria lei havia concedido esse espaço de autonomia, ou seja, nos crimes de ação penal condicionada ou ação penal privada.

\section{CONCLUSÃO}

Este texto chama atenção para o fenômeno da interpretação jurídica e sua indissociabilidade dos efeitos concretos e desiguais na vida das pessoas. De um lado, buscamos expor o debate no campo da dogmática jurídica de direito processual e seu impulso legítimo e aparentemente neutro de classificar instrumentos jurídicos de acordo com sua natureza, área do direito e categorias processuais. De outro, buscamos mostrar como tais debates não acontecem no vácuo, a dogmática jurídica está encarnada na realidade e as diferentes posições jurídico-dogmáticas têm potencial de ampliar ou restringir o acesso das mulheres ao direito à proteção criado pela LMP.

Decisões de primeira instância - que majoritariamente adotam entendimento de que as medidas protetivas são vinculadas a um processo principal - produzem efeitos de gênero, na medida em que impõem ônus ilegítimos às mulheres. Tal entendimento suporta a prática não prevista em lei - de condicionar a proteção ao B.O. ou extinguir a medida protetiva com cíveis e de família. 
o fim do procedimento principal. Tem como consequência burocratizar o acesso da mulher à proteção, submetê-la a procedimentos revitimizadores, limitar as suas alternativas de apoio e suprimir seu espaço de escolha. As disputas interpretativas em torno desse tema chegaram ao STJ e o entendimento que favorece a proteção da mulher foi reconhecido por esse tribunal superior, embora não tenha resolvido a questão nas instâncias inferiores. Isso é particularmente grave no tema que estamos analisando, pois tratamos de medidas emergenciais, de modo que a negação em primeira instância e o tempo de processamento do recurso já impõem em si um custo alto à proteção das mulheres.

A batalha em torno das protetivas revela como uma discussão aparentemente anódina e de taxonomia conceitual - a natureza jurídica do instituto - pode gerar impactos relevantes na vida das mulheres e como o judiciário está disposto a invisibilizar esses impactos.

Este estudo, em última instância, chama a atenção para a importância de desvelar a falta de neutralidade das interpretações jurídicas, perguntando em cada uma delas a questão das mulheres, ou, melhor, dos diferentes grupos de mulheres. Em vários dos relatos que transcrevemos anteriormente, vimos que algumas situações afetam com mais contundência grupos específicos de mulheres, como as que moram em periferias, dependem da pensão do agressor ou têm familiares em situações de drogadição ou envolvimento com o crime. Sabemos que mulheres negras são as mais expostas a situações como essas. Além disso, sabemos que a violência de gênero afeta com mais contundência as mulheres negras - 68\% das mulheres assassinadas no país, em 2018, eram negras, e nessa cifra estamos falando de uma elevada representação de homicídios que aconteceram em casa $(30,4 \%)$, o que é um proxy para vítimas de violência doméstica (IPEA; FBSP, 2020). Isso significa que qualquer orientação jurisprudencial que deixa mulheres vítimas de violência sem proteção tem impacto desproporcional na vida de mulheres negras.

Retomando a citação de Scales, do início do texto, cada interpretação jurídica escolhe privilegiar ou silenciar uma realidade. Por meio de uma interpretação abstrata, aparentemente neutra ou "garantista" sobre a natureza jurídica da medida protetiva, o que os juízes estão dizendo é que a mulher que precisa de proteção urgente só vai ter proteção se decidir processar criminalmente o agressor, mesmo que isso tenha consequências ruins para sua vida ou a de seus filhos. Ou, então, que a mulher que precisa de proteção mas que infelizmente não conseguiu levar testemunhas à delegacia (ou a que teve o "azar" de enfrentar um delegado que se recusou a ouvir as testemunhas no mesmo dia, por exemplo) também não terá proteção, pois o caso penal não "foi para frente". Ou, ainda, que com o fim do processo criminal a medida protetiva será suspensa e, se a mulher quiser, que faça novamente o pedido, traga provas, testemunhas, justifique-se novamente para um juiz, conte novamente sua história, faça de novo toda a "via crucis" para reconquistar o direito à proteção, em uma situação em que a violência nunca cessou.

Quando juízes justificam a necessidade de atrelar a medida protetiva ao processo penal porque, afinal, o homem não pode ficar eternamente com uma medida restritiva em suas 
costas, eles estão na verdade escolhendo uma solução jurídica que aloca ônus e risco às mulheres. Por que não criar nas próprias varas mecanismos de controle periódicos das medidas? Ou, ainda, deixar que o homem, quando achar que for o caso, tenha a iniciativa de solicitar ao juízo a suspensão da medida? Por que a solução que o sistema automaticamente cria é a que significa um ônus para a mulher e que a deixa sem proteção em um momento de emergência, ao passo que poupa o homem do constrangimento ou do ônus de provar que ele não é mais uma fonte de ameaça para a mulher?

Como respondeu uma de nossas entrevistadas a um juiz, que lhe perguntou como é que ele saberia se não há mais violência: "é preciso falar com as mulheres. São elas quem vão dizer". É justamente disso que se trata a teoria feminista do direito: incorporar o ponto de vista das mulheres e pensar em soluções jurídicas que considerem com centralidade a realidade de suas vidas, já que a suposta ausência de ponto de vista até hoje apenas reproduziu desvantagens de gênero, raça e classe.

De outro lado, este estudo também chama atenção para a importância das disputas interpretativas que vêm após a promulgação de uma lei. ${ }^{64} \mathrm{O}$ que está em jogo no debate interpretativo sobre as medidas protetivas é o próprio potencial inovador e multidisciplinar da lei. Afinal, embora ela ofereça soluções que ampliam o arsenal de respostas do direito, a interpretação que condiciona o acesso a essas outras medidas à porta de entrada do direito penal redesenha a política pública criada pela lei.

O que vimos com nossa pesquisa, especialmente na primeira instância, mas também de modo parcial no TJSP, é a interpretação de um instituto inovador de uma lei de caráter integral e voltada à proteção da mulher com uma lógica que não a leva em conta. Para o campo de estudos sobre a mobilização de direitos e seu papel em políticas públicas de igualdade, parece-nos importante identificar que as batalhas político-jurídicas, mesmo após vitórias no legislativo, transitam para o campo da aplicação da lei e dos desenhos institucionais. Nas engrenagens da aplicação do direito e no processo de integração da norma ao ordenamento jurídico e ao funcionamento das estruturas burocráticas, abre-se um novo campo de disputas por interpretações, que impactam diretamente na finalidade da política pública. Por fim, importante também destacar como a disputa no âmbito da dogmática jurídica advém de escolhas anteriores. Como uma de nossas entrevistadas coloca, "se tivesse[m] realmente políticas públicas efetivas que o Executivo tivesse que fazer e fizesse, não teria que jogar tudo para o Judiciário". As disputas interpretativas são um produto de uma escolha anterior, de criar um instituto protetivo a ser administrado pelo sistema de justiça.

64 No caso da LMP, isso tem sido uma marca de sua aplicação desde o início; ver Machado et al. (2012). 
Por fim, indicamos aqui como agenda de pesquisa futura a importância do path dependence $^{65}$ para explicar os fracassos de implementção da LMP. Uma das hipóteses explicativas para a predominância do entendimento das medidas protetivas como cautelares penais é a concentração das ações relacionadas à violência doméstica em varas penais e o déficit de implantação dos JVDs com competência híbrida, como previsto na lei.

O que move um juiz penal é a ocorrência do crime e o seu registro como porta de entrada no sistema de justiça. Nossa hipótese é de que, ao ser aplicada por juízes penais, é a lógica desse campo que perpassaria a aplicação da lei, inclusive dificultando o acesso às necessidades cíveis da mulher em situação de violência. Submetida à racionalidade do juiz penal, a medida protetiva deixa de ter como escopo principal a proteção da mulher. A ideia de proteção de urgência aparece nessa esfera traduzida pelas medidas cautelares, típicas do processo penal, e que em última instância servem para proteger o fim do processo. De outro lado, ao chamar atenção para os custos de se mudar certas práticas, é possível pensar - a partir dos insights de algumas entrevistadas - que juízes penais se sentem mais resguardados ao utilizar o critério de apresentação do B.O. para concessão de protetivas em vez de confiar na palavra da vítima. Seria uma solução “fácil” em situações em que precisam conceder uma decisão rápida com poucos elementos e preservar-se-ia, assim, o "poder geral de cautela” ao não "retirar liberdades" sem que haja uma acusação da vítima e uma chancela de outras organizações como a polícia. Em suma, há um caminho importante a ser investigado sobre os efeitos desse arranjo institucional, que estaria colocando em xeque aquilo que seria uma das grandes inovações da lei. Afinal, o desenho híbrido da lei estaria sendo interpretado com as lentes do passado, que, além de formalistas e compartimentadas, não enxergam a realidade das mulheres.

\section{POST SCRIPTUM}

Em razão da pandemia da Covid-19, a Corregedoria do TJSP publicou o Comunicado CG n. 259/2020, recomendando aos magistrados que prorroguem as MPUs conferidas por prazo determinado e destacando que a LMP não define prazo de duração. Também comunica que o B. O. é prescindível para a instauração de processos relacionados à violência doméstica. ${ }^{66}$ Além disso, também surgiu a possibilidade de lavrar o B. O. on-line por meio do site

65 O path dependence pode ser entendido de uma perspectiva ampla, que considera que a história dos processos importa, ou de uma perspectiva restrita ligada à ideia de increasing returns (retornos crescentes): conforme os processos seguem um determinado caminho, os custos de alterá-lo aumentam e os ganhos de permanecer crescem (PIERSON, 2000).

66 Corregedoria-Geral da Justiça, TJSP. Comunicado CG n. 259/2020. Disponível em: https://www.tjsp.jus.br/ Download/Portal/Coronavirus/Comunicados/Comunicado_CG_N259-2020.pdf. Acesso em: 5 jul. 2020. 
da Polícia Civil do Estado de São Paulo. ${ }^{67}$ Essas medidas foram adotadas em face da situação de isolamento social e dos indícios de aumento da violência doméstica contra a mulher no período. ${ }^{68}$

A conjuntura crítica da pandemia representou uma intervenção externa importante à dinâmica interna do debate jurídico e permitiu uma alteração do cenário que estávamos observando. Conjunturas críticas têm o potencial de gerar mudanças permanentes, mas ainda é cedo para saber se tal orientação prevalecerá com o fim da pandemia ou se o fim da necessidade de isolamento social significará a volta da exigência de que a mulher acesse o sistema pela ida à delegacia. Temos razões para suspeitar de que entendimentos que prejudicam as mulheres têm resiliência no sistema de justiça.

\section{ENTREVISTAS}

1. Advogada e ativista pelos direitos das mulheres do Cladem;

2. Advogada no CDCM em São Paulo;

3. Defensora pública nas varas Cível e de Família, SP;

4. Defensora pública no JVD, SP;

5. Promotora do JVD na Penha, SP;

6. Defensora pública e coordenadora auxiliar do Nudem;

7. Juíza de JVD, SP;

8. Defensora pública e coordenadora auxiliar do Nudem;

9. Gerente em CDCM em São Paulo;

10. Juíza em vara criminal na região metropolitana de São Paulo.

67 Delegacia eletrônica da Polícia Civil do Estado de São Paulo. Disponível em: https://www.delegaciaeletronica.policiacivil.sp.gov.br/ssp-de-cidadao/pages/comunicar-ocorrencia/violencia-domestica/triagem-de-vitima. Acesso em: 5 jul. 2020.

68 Pagnan (2020). 


\section{AGRADECIMENTOS}

As autoras agradecem à Mariana Zambom, Mariana Limeira, Alexandre Nogueira e Muriel Aronis pela assistência na pesquisa. Agradecem também a Matheus de Barros e Taís Penteado pela leitura de versões anteriores deste texto. A Luísa Ferreira, pelas conversas que vieram depois da conclusão deste texto. E, muito especialmente, às profissionais que entrevistaram, pelo tempo e disposição de dividirem as histórias de suas batalhas. Agradecem, ainda, ao CNPq e à FGV pela bolsa concedida entre 2015 e 2016 para realização das atividades de campo.

\section{REFERÊNCIAS}

ALVAREZ, Sonia E. Latin American Feminisms "Go Global": Trends of the 1990s and Challenges for the New Millennium. In: ALVAREZ, Sonia E.; DAGNINO, Evelina; ESCOBAR, Arturo (org.). Cultures of Politics/Politics of Culture: Re-visioning Latin American social movements. Boulder, CO.: Westview Press, 1998. p. 293-324.

AMANTINI, Stephani Gagliardi. A natureza jurídica das medidas protetivas de urgência previstas na Lei 11.340/06. 2016. 146 f. Trabalho de Conclusão de Curso (Graduação em Direito) - Faculdade de Direito, Universidade de São Paulo, São Paulo, 2016.

ÁVILA, Thiago Pierobom de. Medidas protetivas da Lei Maria da Penha: natureza jurídica e parâmetros decisórios. Revista Brasileira de Ciências Criminais, São Paulo, v. 157, p. 131-172, jul. 2019. versão on-line.

BARSTED, Leila L. Lei Maria da Penha: uma experiência bem-sucedida de advocacy feminista. In: CAMPOS, Carmen H. (org.) Lei Maria da Penha comentada em uma perspectiva jurídico-feminista. Rio de Janeiro: Lumen Juris, 2011. p. 13-37.

BARSTED, Leila; LAVIGNE, Rosane. Proposta de lei de violência doméstica contra as mulheres. Carta da CEPIA, v. 3, n. 10, dez. 2002. Disponível em: http: / / cepia.org.br/wp-content/uploads/2017/11/ cartadacepia10.pdf. Acesso em: 27 out. 2020.

BARTLETT, Katharine T. Feminist legal methods. Harvard Law Review, v. 103, n. 4, p. 829-888, fev. 1990. Disponível em: https://www.jstor.org/stable/1341478. Acesso em: 25 ago. 2020. 
BECHARA, Julia Maria Seixas. Violência doméstica e natureza jurídica das medidas protetivas de urgência. Revista Jus Navigandi, ano 15, n. 2661, 2010. Disponível em: https://jus.com.br/artigos/17614. Acesso em: 17 jun. 2019.

BRASIL. Secretaria Nacional de Enfrentamento à Violência contra as Mulheres. Secretaria de Políticas para as Mulheres - Presidência da República. Política Nacional de Enfrentamento àViolência Contra as Mulheres, Brasília, 2011.

BRASIL. Superior Tribunal de Justiça. RHC 94.320/BA, Quinta Turma, Rel. Ministro Felix Fischer, julgado em 09.10.2018, publicado em 24.10.2018. Brasília, 2018.

BRASIL. Superior Tribunal de Justiça. AgRg no REsp 1566547/MG, Quinta Turma, Rel. Ministro Joel Ilan Paciornik, julgado em 27.06.2017, publicado em 01.08.2017. Brasília, 2017a.

BRASIL. Superior Tribunal de Justiça. RHC 33.259/PI, Quarta Turma, Rel. Ministro Ribeiro Dantas, julgado em 17.10.2017, publicado em 25.10.2017. Brasília, 2017b.

BRASIL. Superior Tribunal de Justiça. REsp 1419421/GO, Quarta Turma, Rel. Ministro Luis Felipe Salomão, julgado em 11.02.2014, publicado em 07.04.2014. Brasília, 2014a.

BRASIL. Supremo Tribunal Federal. ADI 4424, Tribunal Pleno, Rel. Ministro Marco Aurélio, julgado em 09.02.2012, publicado em 01.08.2014, 2014. Brasília, 2014b.

BUENO, Cassio Scarpinella. Curso sistematizado de direito processual civil: teoria geral do direito processual civil. 8. ed. São Paulo: Saraiva, 2014.

CALAZANS, Myllena; CORTES, Iáris. O processo de criação, aprovação e implementação da Lei Maria da Penha. In: CAMPOS, Carmen H. de (org.). Lei Maria da Penha comentada em uma perspectiva jurídicofeminista. Rio de Janeiro: Lumen Juris, 2011. p. 39-63.

CAMPOS, Carmen H. de. Desafios na implementação da Lei Maria da Penha. Revista Direito GV, São Paulo, v. 11, n. 2, p. 391-406, 2015. Disponível em: https://www.scielo.br/scielo.php?pid=S180824322015000200391\&script=sci_abstract\&tlng=pt. Acesso em: 25 ago. 2020.

CAMPOS, Carmen H. de. Lei Maria da Penha: mínima intervenção punitiva, máxima intervenção penal. Revista Brasileira de Ciências Criminais, São Paulo, n. 73, p. 244-267, jul. /ago. 2008.

CAMPOS, Carmen H. de; CARVALHO, Salo de. Tensões atuais entre a criminologia feminista e a criminologia crítica: a experiência brasileira. In: CAMPOS, Carmen H. de (org.). Lei Maria da Penha comentada em uma 
perspectiva jurídico-feminista. Rio de Janeiro: Lumen Juris, 2011. p. 143-171.

CEPIA - Cidadania, Estudos, Pesquisa, Informação e Ação. Violência contra a mulher e acesso à justiça. Estudo comparativo sobre a aplicação da Lei Maria da Penha em cinco capitais: relatório final. Rio de Janeiro: Cepia/Ford, 2013. Disponível em: https: / /assets-compromissoeatitude-ipg.sfo2.digitaloceanspaces.com/2013/11/ CEPIA_PesqVCMulhereAcessoaJustica_out2013.pdf. Acesso em: 5 jul. 2020.

CERQUEIRA, Daniel et al. Avaliando a efetividade da Lei Maria da Penha. Brasília: Ipea, 2015.

CFEMEA. Mobilização por uma Lei Integral de Enfrentamento da Violência Doméstica contra as Mulheres: 15 de abril de 2005. Disponível em: https: / /www.cfemea.org.br/index.php/colecao-femea-e-publicacoes/ publicacoes / 4316-campanha-por-uma-lei-integral-de-enfrentamento-a-violencia-domestica-e-familiarcontra-as-mulheres. Acesso em: 13 nov. 2020.

COVER, Robert M.Violence and the Word. Yale Law Journal, v. 95, n. 8, p. 1601-1630, jul. 1986. Disponível em: https: / / digitalcommons.law.yale.edu/cgi/viewcontent. cgi?article=7025\&context=ylj. Acesso em: 24 ago. 2020.

DIDIER JR., Fredie; OLIVEIRA, Rafael A. A Lei Maria da Penha e o novo CPC. In: SICA, Heitor; COSTA, Eduardo Fonseca da (org.). Repercussões do novo CPC: volume 9: legislação processual extravagante. Salvador: JusPodivm, 2016. p. 137-162.

DINAMARCO, Cândido Rangel. Instituições de direito processual civil. 9. ed. São Paulo: Malheiros, 2017.

GUARANHA, Olívia L. C. As medidas protetivas da Lei Maria da Penha: uma análise qualitativa. Relatório PIBIC. São Paulo: Fundação Getulio Vargas, 2016.

IPEA; FÓRUM BRASILEIRO DE SEGURANÇA PÚBLICA (FBSP). Atlas da violência 2020. Disponível em: https: / / forumseguranca.org.br/publicacoes_posts/atlas-da-violencia-2020/. Acesso em: 31 ago. 2020 .

IPEA; FÓRUM BRASILEIRO DE SEGURANÇA PÚBLICA (FBSP). Atlas da violência 2019. Disponível em: https://www.ipea.gov.br/portal/images/stories/PDFs/relatorio_institucional/190605_atlas_da_ violencia_2019.pdf. Acesso em: 23 ago. 2020.

LAVIGNE, Rosane M. R.; PERLINGEIRO, Cecília. Das medidas protetivas de urgência - artigos 18 a 21. In: CAMPOS, Carmen H. de (org.). Lei Maria da Penha comentada em uma perspectiva jurídico-feminista. Rio de Janeiro: Lumen Juris, 2011. p. 289-305. 
LIMA, Fausto Rodrigues de. Da atuação do Ministério Público Público: artigos 25 e 26. In: CAMPOS, Carmen H. de (org.). Lei Maria da Penha comentada em uma perspectiva jurídico-feminista. Rio de Janeiro: Lumen Juris, 2011. p. 327-335.

LINS, Beatriz Accioly. A lei nas entrelinhas: a Lei Maria da Penha e o trabalho policial em duas Delegacias de Defesa da Mulher de São Paulo. 2014. 174 f. Dissertação (Mestrado) - Faculdade de Filosofia, Letras e Ciências Humanas, Universidade de São Paulo, São Paulo, 2014.

LOPES, João Batista; LOPES, Maria Elizabeth de Castro. Tutela inibitória. In: CAMPILONGO, Celso Fernandes; GONZAGA, Alvaro de Azevedo; FREIRE, André Luiz; BUENO, Cassio Scarpinella; OLIVEIRA NETO, Olavo (coord.). Enciclopédia jurídica da PUC-SP: Processo Civil. São Paulo: Pontifícia Universidade Católica de São Paulo, 2017. Disponível em: https: / / enciclopediajuridica.pucsp.br/verbete/164/edicao1/tutela-inibitoria. Acesso em: 21 jun. 2020.

MACHADO, Marta Rodriguez de Assis; MATSUDA, Fernanda E.; GIANNATTASIO, Arthur R. C.; COUTO, Maria Cláudia G.; TOZI, Thalita S.; SILVA, Mariana L. C.; CHRYSSAFIDIS, Larissa C.; PRYZBYLSKI, Larissa C. A violência doméstica fatal: o problema do feminicidio íntimo no Brasil. Brasília: Ministério da Justiça, 2015. v. 1, 67 p.

MACHADO, Marta Rodriguez de Assis; RODRIGUEZ, José Rodrigo; PROL, Flávio Marques; JUSTINO, Gabriela; GANZAROLLI, Marina Zanata; ELIAS, Renata do Vale. Disputando a aplicação das leis: a constitucionalidade da Lei Maria da Penha nos tribunais brasileiros. Sur. Revista Internacional de Direitos Humanos, v. 9, n. 16, p. 65-88, jun. 2012. Disponível em: https://sur.conectas.org/disputando-aplicacaodas-leis/. Acesso em: 25 ago. 2020.

MACIEL, Débora A. Ação coletiva, mobilização do direito e instituições políticas: o caso da Campanha da Lei Maria da Penha. Revista Brasileira de Ciências Sociais, São Paulo, v. 26, n. 77, p. 97-112, out. 2011. Disponível em: http: / / www.scielo.br/scielo.php?script=sci_arttext\&pid=S0102-69092011000300010\& $\operatorname{lng}=$ en\&nrm $=$ is. Acesso em: 25 ago. 2020.

MATSUDA, Mari J. Looking to the bottom: critical legal studies and reparations. Harvard Civil RightsCivil Liberties Law Review, v. 22, p. 323-399, 1987.

MONTE, Nalida C.; NADER, Thais H. O. C. Da desvinculação da medida protetiva ao procedimento criminal. In: DEFENSORIA PÚBLICA DO ESTADO DO RIO DE JANEIRO. Gênero, sociedade e defesa de direitos: a Defensoria Pública e a atuação na defesa da mulher. Rio de Janeiro: Defensoria Pública do Estado do Rio de Janeiro, 2017. p. 166-193. 
OBSERVE. Observatório pela Aplicação da Lei Maria da Penha. Condições para aplicação da Lei n. 11.340/2006 (Lei Maria da Penha) nas Delegacias Especializadas de Atendimento à Mulher (DEAMs) e nos Juizados de Violência Doméstica e Familiar nas capitais e no Distrito Federal: Relatório Final. Salvador: Observe, 2010. Disponível em: http://www.observe.ufba.br/_ARQ/Relatorio\%20apresent\%20e\%20DEAMs.pdf. Acesso em: 25 ago. 2020.

PAGNAN, Rogério. Ocorrências de violência doméstica saltam 20\% em SP na quarentena. Folha de S.Paulo, 20 abr. 2020. Disponível em: https://www1.folha.uol.com.br/cotidiano/2020/04/ocorrenciasde-violencia-domestica-saltam-20-em-sp-na-quarentena.shtml. Acesso em: 13 nov. 2020.

PASINATO, Wânia. Acesso à justiça e violência doméstica e familiar contra as mulheres: as percepções dos operadores jurídicos e os limites para a aplicação da Lei Maria da Penha. Revista Direito GV, São Paulo, v. 11, n. 2, p. 407-428, 2015a.

PASINATO, Wânia. Oito anos de Lei Maria da Penha: entre avanços, obstáculos e desafios. Revista Estudos Feministas, v. 23, n. 2, p. 533-545, 2015b.

PIERSON, Paul. Increasing Returns, Path Dependence, and the Study of Politics. American Political Science Review, v. 94, n. 2, 2000.

PIRES, Amom A. A opção legislativa pela política criminal extrapenal e a natureza jurídica das medidas protetivas da Lei Maria da Penha. Revista do Ministério Público do Distrito Federal e Territórios, Brasília, v. 1, n. 5, p. 121-168, 2011. Disponível em: https://www.mpdft.mp.br/portal/pdf/comunicacao/site/ Revista_5.pdf. Acesso em: 25 ago. 2020.

SAGOT, Montserrat. Ruta crítica de las mujeres afectadas por la violencia intrafamiliar en América Latina: estudios de caso de diez países. [S.1.]: Pan American Health Org, 2000.

SÃO PAULO. Tribunal de Justiça. Agravo de Instrumento 2270844-93.2019.8.26.0000, 9ª Câmara de Direito Criminal, Relator(a): Grassi Neto, julgado 20.02.2020, registro em 04.03.2020. São Paulo, 2020.

SÃO PAULO. Tribunal de Justiça. Apelação Cível 1000517-04.2018.8.26.0601, 2 ${ }^{\mathrm{a}}$ Câmara de Direito Privado, Relator(a): Rosangela Telles, julgado em 11.06.2019, registro em 11.06.2019. São Paulo, 2019a.

SÃO PAULO. Tribunal de Justiça. Apelação Criminal 0011695-55.2017.8.26.0001; 8 a Câmara de Direito Criminal, Relator(a): Alcides Malossi Junior julgado em 23.05.2019, registro em 28.05.2019. São Paulo, 2019b.

SÃO PAULO. Tribunal de Justiça. Apelação Criminal 0019376-78.2014.8.26.0002, $8^{\text {a }}$ Câmara de Direito Criminal, Relator(a): Grassi Neto, julgado em 22.03.2018, registro em 27.03.2018. São Paulo, 2018. 
SÃO PAULO. Tribunal de Justiça. Mandado de Segurança Criminal 2014212-02.2017.8.26.0000, $7^{\mathrm{a}}$ Câmara de Direito Criminal, Relator(a): Reinaldo Cintra, julgado em 21.06.2017, registro em 26.06.2017. São Paulo, 2017a.

SÃO PAULO. Tribunal de Justiça. Mandado de Segurança Criminal 2062183-80.2017.8.26.0000, $12^{a}$ Câmara de Direito Criminal, Relator(a): Paulo Rossi, julgado em 07.06.2017, registro em 19.06.2017. São Paulo, 2017b.

SÃO PAULO. Tribunal de Justiça. Mandado de Segurança Criminal 2146796-33.2017.8.26.0000, $6^{a}$ Câmara de Direito Criminal, Relator(a): Marcos Correa, julgado em 14.09.2017, registro em 18.09.2017. São Paulo, 2017c.

SÃO PAULO. Tribunal de Justiça. Apelação Criminal 0020061-76.2014.8.26.0005, 10 Câmara Criminal Extraordinária, Relator(a): Nuevo Campos, julgado em 16.12.2016, registro em 19.12.2016. São Paulo, 2016.

SCALES, Ann. Feminist legal method: not so scary. UCLAWomen’s Law Journal, v. 2, p. 1-34, 1992. Disponível em: https: / / heinonline.org/HOL/P?h=hein.journals/uclawo2\&i=7. Acesso em: 28 out. 2020.

SENADO FEDERAL. Instituto de Pesquisa DataSenado; Observatório da Mulher contra a Violência; Secretaria de Transparência. Violência doméstica e familiar contra a mulher. Brasília: DataSenado, 2017. Disponível em: https: / /www12.senado.leg.br/institucional/datasenado/arquivos/aumenta-numerode-mulheres-que-declaram-ter-sofrido-violencia. Acesso em: 25 ago. 2020.

SENADO FEDERAL. Comissão Parlamentar Mista de Inquérito com a finalidade de investigar a situação da violência contra a mulher no Brasil e apurar denúncias de omissão por parte do poder público com relação à aplicação de instrumentos instituídos em lei para proteger as mulheres em situação de violência. Relatório Final. Brasília: Senado Federal, 2013. Disponível em: https://www12.senado.leg.br/institucional/ omv/entenda-a-violencia/pdfs/relatorio-final-da-comissao-parlamentar-mista-de-inquerito-sobre-aviolencia-contra-as-mulheres. Acesso em: 25 ago. 2020. 


\section{COMO CITAR ESTE ARTIGO:}

MACHADO, Marta R. de Assis; GUARANHA, Olívia Landi C. Dogmática jurídica encarnada: a disputa interpretativa em torno das medidas protetivas de urgência e suas consequências para a vida das mulheres. Revista Direito GV, v. 16, n. 3, set./dez. 2020, e1972. doi: http:// dx.doi.org/10.1590/2317-6172201972.

\section{Marta R. de Assis Machado}

Professora em REgIME de PERÍodo INTEgRaL da EsCOLA de Direito de São Paulo da Fundação Getulio Vargas (FGV DIREITO SPI. CoORdenadora do Núcleo de Estudos SObRe 0 Crime e a Pena da FGV DiReito SP. CoORdenadora do Programa de Mestrado e Doutorado Acadêmico da FGV

DiREITO SP. Pesquisadora Permanente do Centro Brasileiro de Análise e Planejamento. Doutora e mestre Pelo departamento de Filosofia e Teoria Geral do Direito da Faculdade de Direito da Universidade de São Paulo (USP), INSTITUIÇÃO NA QUAL TAMBÉM SE GRADUOU.

Marta.Machadolafgv.br

\section{Olívia Landi C. Guaranha}

Mestranda em Administração Pública e Governo pela Escola de Administração de Empresas de São Paulo da

Fundação Getulio Vargas (FGV EAESP). Graduada em Direito pela Universidade de São Paulo (USP). Advogada.

oliguaranhalagmail.com 